\title{
The Attitudes of Nurses Towards Internship in the Republic of Croatia
}

1 Ivica-Tvrtko Vuković

2 Marija Brdarević

2 Snježana Čukljek

2 Janko Babić

1 Clinical Hospital Merkur, Zagreb, Croatia

2 University of Applied Health Sciences, Zagreb, Croatia

Article received: 21.12.2018.

Article accepted: 12.03.2019.

DOI: $10.24141 / 2 / 3 / 1 / 7$

Author for correspondence:

Marija Brdarević

University of Applied Health Sciences

Mlinarska 38, Zagreb, Croatia

E-mail: marija.brdarevic@zvu.hr

Keywords: internship, nursing, advantages, disadvantages, attitudes, interns

\section{Abstract}

The internship in health care is regulated by the Rules and Regulations on Internship of Health Care Providers. One of the measures of the Croatian Institute for promoting employment of interns in health care is "Professional Training for Work Without Establishing an Employment Relationship".

The aim of this research is to determine the attitudes towards internship and to determine whether there is a statistically significant difference between the attitudes of currently employed nurses and those currently doing an internship.

The research was conducted through the Internet, using an anonymous questionnaire containing 10 questions, out of which 8 were closed-ended and 2 open-ended questions. A total of 306 respondents were interviewed, of whom 232 were nurses and 49 nursing interns. When asked whether internship is necessary in health care, $98.4 \%$ of the respondents answered positively, with the majority of interns (75.3\%) considering that there is a need for changes in internship. The results of the chi-square test suggest that there are statistically significant differences in the attitudes of employed respondents and interns in the answers to 5 questions. The interns rated their knowledge of internship worse than healthcare workers and workers in other systems. Interns associate internship with exploitation, while employed nurses mention that it reminds them of training for independent work. Most healthcare professionals would like someone close to them to have the right/obligation to do internship.

By analyzing the results of the attitudes towards internship, a statistically significant difference between currently employed nurses and nursing interns was established. It is felt that youth training should be the responsibility of the employers who should provide adequate education and continuous monitoring of new workers. 


\section{Introduction}

One of the current topics related to recently graduated bachelors of nursing is the discontinuation of internship. So far, every bachelor in health care has had the legal right, but also the obligation, to complete a one-year internship, and after completing the internship, pass a state exam. When Croatia joined the European Union, the obligation to do internships was discontinued for students enrolled in a nursing study programme after 1 July 2013, so that students can, upon graduation, directly compete in the labor market as licensed health professionals.

\section{Education of nurses in the Republic of Croatia}

Until the school year 2010/2011, secondary school education of nurses in Croatia lasted 4 years, during which students were taught both general and professional subjects. After finishing secondary school, nurses were required to complete a one-year internship to become licenced nurses and be able to compete in the labor market. The harmonization with the requirements of the European Union and the Directive 2005/36 started in the year 2010/2011. The Directive stipulates the minimum required number of 4600 hours of training for the education of nurses. Education is carried out at all levels of health care.

From the school year 2010/2011 the education has lasted 5 years, according to the principle $2+3$ (two years of general education and 3 years exclusively for professional subjects). After completing secondary education, the title nurse with a direct enrollment in the Register of the Croatian Nursing Council is obtained without the obligation to do internship and take a state exam.

For the enrollment into the undergraduate study of nursing, the European Union Directives require a twelve-year general education and recommendation for the enrollment of students who are 18 or at least 17 years of age. Directive 2005/36/EC details the minimum requirements for the education of nurses, which stipulate that: education should last at least three years or 4600 hours of theoretical and clinical training, theoretical classes should take up one third of the total duration of the study program and clinical practice should take up one half of the total duration of the study program. The Directive also prescribes the mandatory contents of the education program for nurses (1).

After thematic evaluation in 2013, upon the request of the Ministry of Science and Sport, in 2014 a study program of Nursing was created, the so-called Core curriculum. This is a compulsory part of the nursing studies, unique for the whole of Croatia. The compulsory part bears 158 of the total of 180 ECTS credits. The other 22 credits refer to elective courses that higher education institutions can choose for themselves. Therefore, from the academic year 2015/2016, at all undergraduate nursing studies in the Republic of Croatia, the compulsory courses follow an identical program (2).

Upon completion of the undergraduate study of nursing, students may continue their studies at specialist graduate professional studies or university graduate studies in the Republic of Croatia. Specialist graduate professional studies last two years, bear 120 ECTS credits and award a title of a graduate nurse. Nursing specialist graduate professional studies are held at the University of Applied Health Sciences in Zagreb and the University of Dubrovnik study programe of Nursing. University graduate nursing studies also last for two years and bear 120 ECTS credits. The total number of credits obtained by completing undergraduate and graduate studies is at least 300 ECTS credits. By completing the undergraduate and graduate university studies, the academic title of Master of Nursing is acquired.

After completing graduate university studies, there is a possibility of further education in related postgraduate studies. Postgraduate university study usually lasts three years. Upon completion of postgraduate studies a student acquires the academic title of a Doctor of Science. Universities can organize postgraduate specialist studies that last one to two years and award the academic title of a university specialist of the respective profession (3). One such study program is organized by the Libertas International University in Zagreb, which offers a university postgraduate study of Quality Management in Healthcare, which awards the academic title of the Master of Quality Management in Healthcare.

As in European countries and the United States, the education of nurses in the Republic of Croatia is continually raised to a higher academic level. Nurses 
have been gradually receiving the possibility of university-level education and the possibility to obtain a university degree. Today, students at the university graduate study of nursing have completed their graduate studies ten to thirty years ago and have a long-term working experience in health care (4).

After completing the education at the bachelor or graduate level the need for education and further professional development does not stop. Nurses are required to continually renew their existing knowledge and acquire new ones in order to ensure safe and quality care. The continual development of medical, as well as nursing sciences, requires lifelong learning. Obligatory continuous training is required in Croatia for the purpose of renewing licences for independent work (2).

In the contemporary world, employers confirm that the knowledge that pupils are generally acquiring is not adequate. Graduates receive too much general and not enough practical knowledge, therefore, additional courses and other educational programs need to be organized in order for graduates to acquire appropriate practical knowledge (5).

\section{Nursing internship}

Nursing internship in the Republic of Croatia, as well as its requirements and implementation, have changed over history. In 2011, the Rules and Regulations on Internship of Health Care Providers came into force.

According to the Rules, internship is a supervised work whereby a health worker is trained for independent work. It is carried out according to a set program, which determines the schedule and duration of work at certain professional units, as well as professional activities which prepare a person for independent work (6).

Although internship has been discontinued for students who enrolled in the nursing studies after July 1,2013 , the Rules are still in force for students who have enrolled in the nursing study before that date. The reason for this is that the study until then was not harmonized with the European Directive 2005/36/EC, which stipulates the number of hours required for bachelors of nursing, without the need for doing an internship.

The Croatian Employment Service has issued various types of measures and support for education, train- ing and employment. One of them is professional training for work without establishing a working relationship (7).

This type of training is used for nursing internship. It lasts 12 months, the requirements are the proper fulfillment of obligations and obtaining signatures of the heads of departments as well as head nurses of the required departments and clinics, where interns must work during their internship. At the primary health care level, the intern does his or her internship in family medicine, pediatrics, and community nursing - where he has the opportunity to participate in the education of the population under the supervision of a community nurse. However, most of their internship is done in a hospital at different departments. The intern goes through surgery departments such as abdominal, vascular, thoracic and traumatology department. He also visits internal medicine departments such as gastroenterology, nephrology and cardiology departments - depending on the employer's options. Among others, there is also a clinic for infectious diseases, department for neurology, psychiatry and gynecology. The employer ensures that the intern works at all the required departments in the health institution. If the institution does not have all the departments, the intern is sent to another healthcare institution as agreed with that institution.

An intern receives financial compensation which is currently $2751 \mathrm{kn}$, as well as the reimbursment of the costs of state examination. Formerly, financial compensation depended on the choice of the employer, and in some cases it was not received, and sometimes it amounted to $75 \%$ of the salary for that job. When introducing the measure of internship, the compensation was set at $1600 \mathrm{kn}$, then it amounted to $2400 \mathrm{kn}, 2620 \mathrm{kn}$, and in 2018 - $2751 \mathrm{kn}$.

Upon completion of the internship, the intern is required to pass a state exam in order to get a licence for independent work necessary for employment. The content of the state exam is defined by the Rules and Regulations on Internship of Health Care Providers. For nurses the exam consists of two parts; general and professional. The general section covers the Constitutional Order of the Republic of Croatia, the Healthcare Act, Act on Mandatory Health Insurance, and the Labor and Pension Insurance Act. The professional part of the exam comprises questions related to the nursing care of patients and nursing care in primary health care (5). 
There is another employment measure that can be used to hire nurses, and it is called Support for Employment for Gaining First Working Experience/ Internship (8). This measure can be used by unemployed persons without any working experience in the profession. It lasts for 12 months, and the financial compensation amounts to $100 \%$ of the amount of the intern salary, which is $85 \%$ of the salary for that workplace, and in accordance with the Regulation on job titles and complexity coefficients in the civil service and the cost of transport in accordance with the Decision of the Management Board.

During internship, each intern has a mentor who should have a relevant occupation, level of education, or work experience (at least three years of work experience in the jobs that the intern will be doing) and have an elaborated program of the internship. If the mentor does not have the suitable occupation and level of education, the employer authenticates the experience of the mentor by providing a document from the Croatian Pension Insurance Institute or the employment contract.

\section{Aim}

The aim of the research is to determine the attitudes of nurses towards internship and to determine whether there is a statistically significant difference between the attitudes of currently employed nurses and those currently doing internship.

\section{Methods}

The research was conducted using surveys which were collected and analysed using the web portal Google forms. There was a total of 10 questions out of which 8 were multiple choice questions and 2 were open-ended questions.

The study lasted for 16 days (28 May 2018 - 12 June 2018). Respondents filled out the surveys anonymously. The first question differentiates between the respondents, as it make a difference between the employed nurses, nurse interns and non-healthcare workers. The statistically significant difference between the respondents was determined by the chisquare test, with the significance level set at $p<0.05$.

A total of 306 respondents answered the survey which was available in the digital form and published on social networking sites by nursing interns and nurses.

The research was done as part of the final paper at the University of Applied Health Sciences in Zagreb, with the approval of the Ethics Committee of the Clinical Hospital Merkur. The results obtained from the multiple choice questions are shown in numbers and percentages.

\section{Results}

The majority of the respondents are healthcare professionals, i.e. nurses $(232,75.8 \%)$, while there is a smaller number of nursing interns $(49,16 \%)$ and non-healthcare workers (25, $8.2 \%)$.

Half of the respondents $(154,50.3 \%)$ think that their knowledge of the internship system is excellent, while 99 (32.4\%) consider their knowledge as very good, 44 (14.4\%) as sufficient, and 9 (2.9\%) as poor.

In Table 1 it can be seen that there is a statistically significant difference in the knowledge of the internship system with regard to the workplace of the respondents, where the interns rated their knowledge as poorer. In the analysis of this and other chi- 


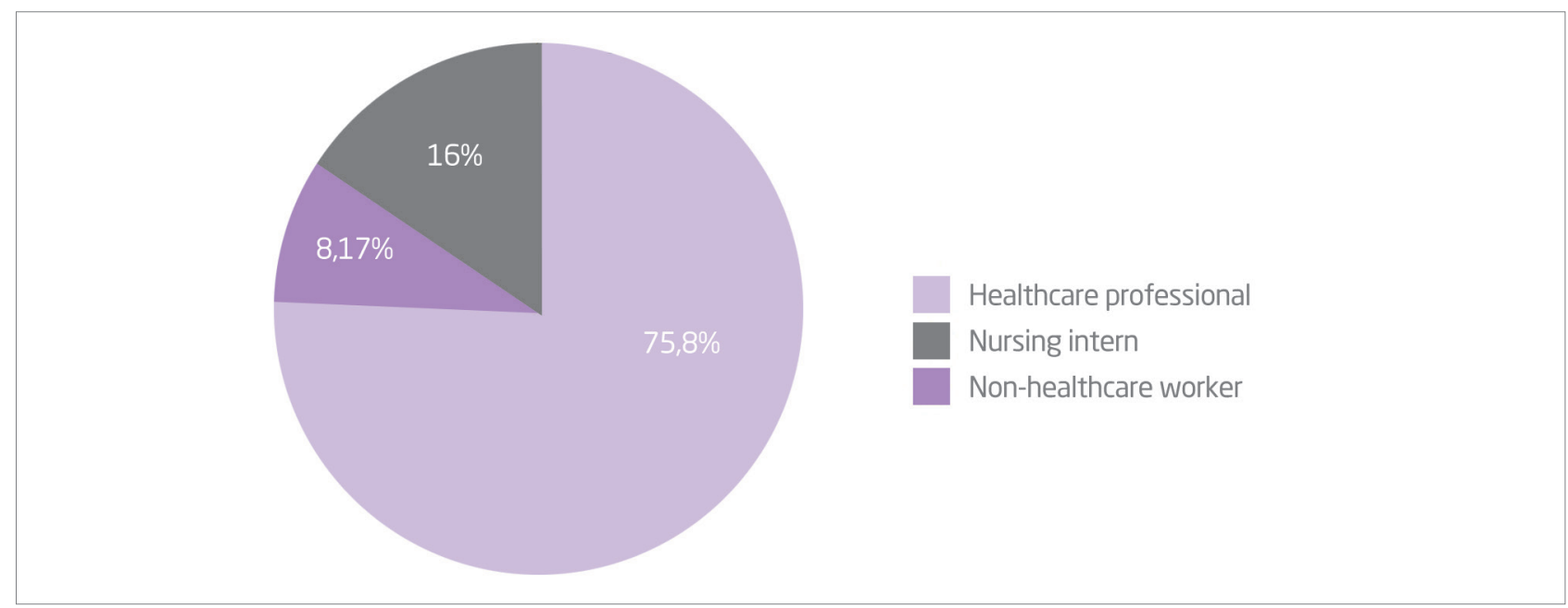

Graph 1. Status of respondents in the healthcare system

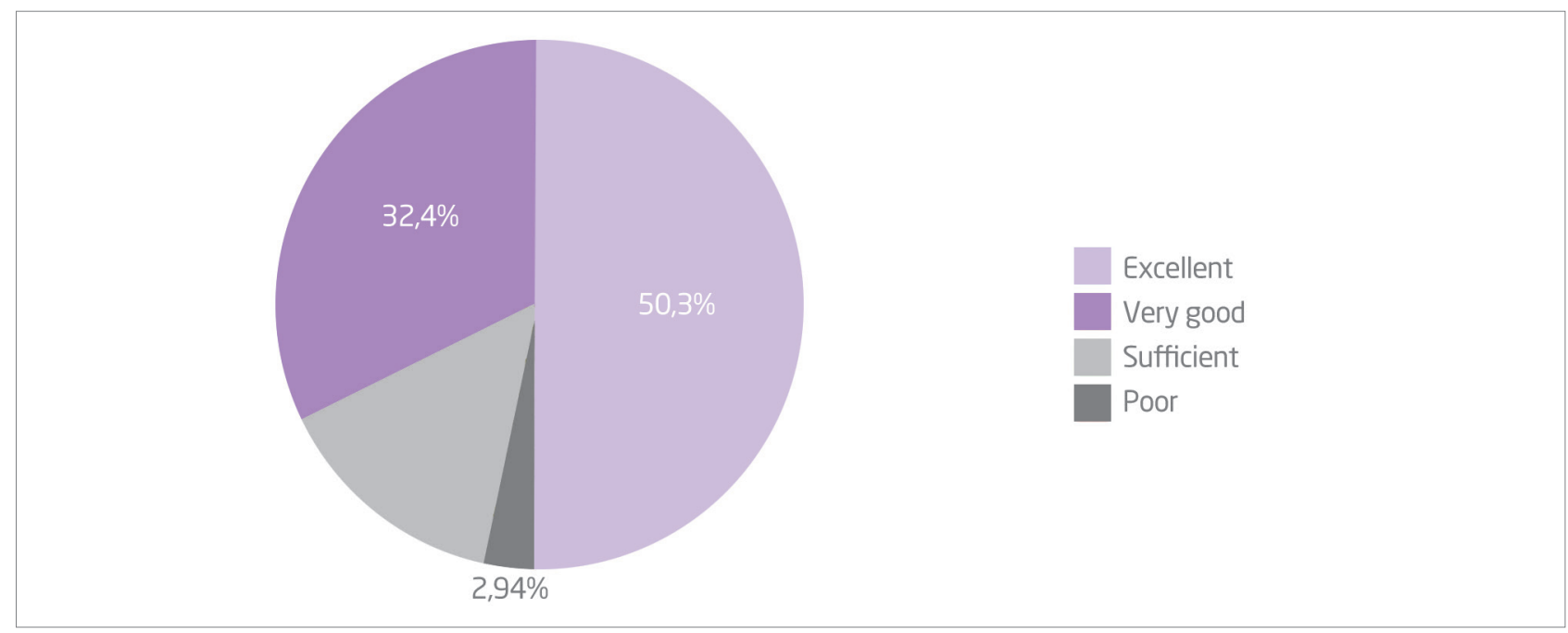

Graph 2. Question 2: "What is your knowledge of the internship system?"

squares, non-healthcare workers were not included, so that the statistical strength of the chi-squares is higher, also taking into consideration that the aim of the research is to determine whether there are differences between healthcare professionals and those doing an internship in health care.

152 respondents, or $49.7 \%$, associate internship with training for independent work. 79 respondents, or $25.8 \%$, associate it with settling into the work process, while 73 , or $23.9 \%$ of the respondents, consider it to be exploitation, and 2 of them, or $0.7 \%$, consider it to be something else.

Table 2 shows that there is a statistically significant difference in the association that the research participants have with regard to the internship, and taking into consideration their workplace. Nursing interns mostly associate internships with exploitation (42.9\%), while healthcare workers $(55.7 \%)$ usually associate internship with training for independent work. In order to increase the statistical strength of the chisquare test, the answer "Other" chosen by only two participants $(0.7 \%)$ was exempt from the analysis.

Of the total number of respondents (156), 51\% think that internship is definitely needed in health care, 145 of them (47.4\%) think it is needed, however, with certain changes introduced, and 5 of them (1.6\%) think that internship is not needed.

Furthermore, there is a statistically significant difference between the groups of respondents as to whether internship in health care is needed, with the 
Table 1. Chi-square test of the differences between the groups in the answer to the question "What is your knowledge of the internship system?"

\begin{tabular}{|c|c|c|c|c|c|c|c|}
\hline & & & \multicolumn{4}{|c|}{ What is your knowledge of the internship system? } & \multirow{2}{*}{ Total } \\
\hline & & & Excellent & Very good & Sufficient & Poor & \\
\hline \multirow{6}{*}{$\begin{array}{r}\text { Your status in } \\
\text { the healthcare } \\
\text { system: }\end{array}$} & \multirow{2}{*}{$\begin{array}{l}\text { Employed in } \\
\text { health care }\end{array}$} & Frequency & 124 & 68 & 35 & 5 & 232 \\
\hline & & Percentage & $53.4 \%$ & $29.3 \%$ & $15.1 \%$ & $2.2 \%$ & $100 \%$ \\
\hline & \multirow{2}{*}{$\begin{array}{r}\text { Healthcare } \\
\text { intern }\end{array}$} & Frequency & 16 & 23 & 6 & 4 & 49 \\
\hline & & Percentage & $32.7 \%$ & $46.9 \%$ & $12.2 \%$ & $8.2 \%$ & $100 \%$ \\
\hline & \multirow{2}{*}{ Total } & Frequency & 140 & 91 & 41 & 9 & 281 \\
\hline & & Percentage & $49.8 \%$ & $32.4 \%$ & $14.4 \%$ & $3.2 \%$ & $100 \%$ \\
\hline
\end{tabular}

Chi-square $=12.177 ; \mathrm{df}=3 ; p<0.01$

Table 2. Chi-square test of the differences between the groups in the answer to the question "What is your association when you find out that someone is doing an internship?"

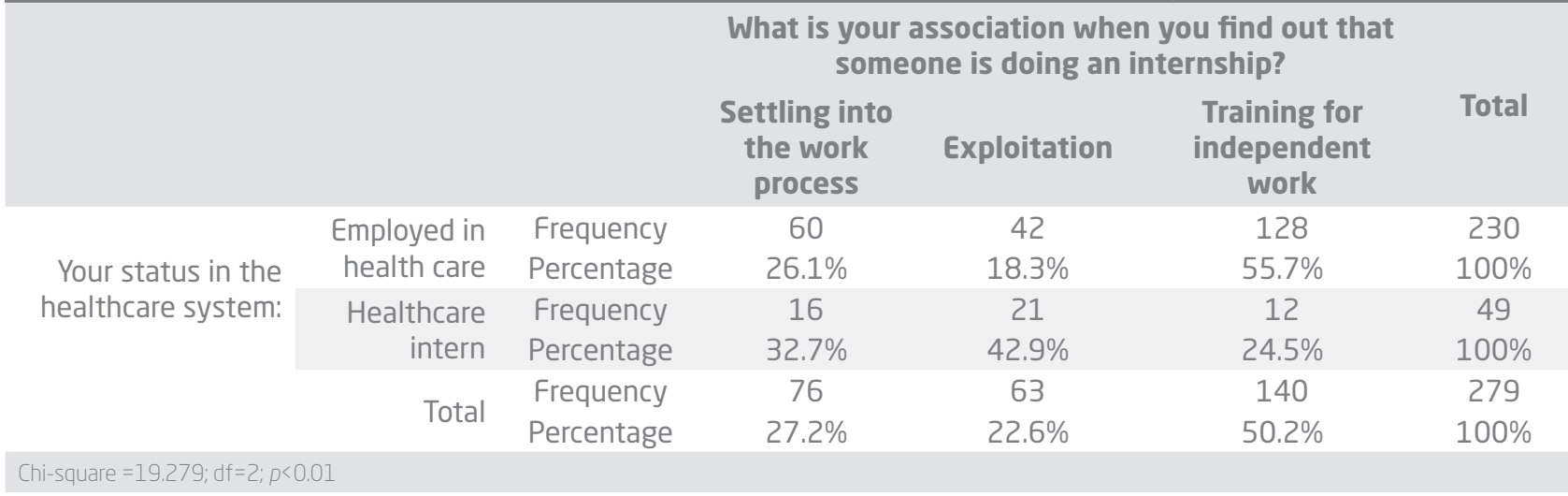

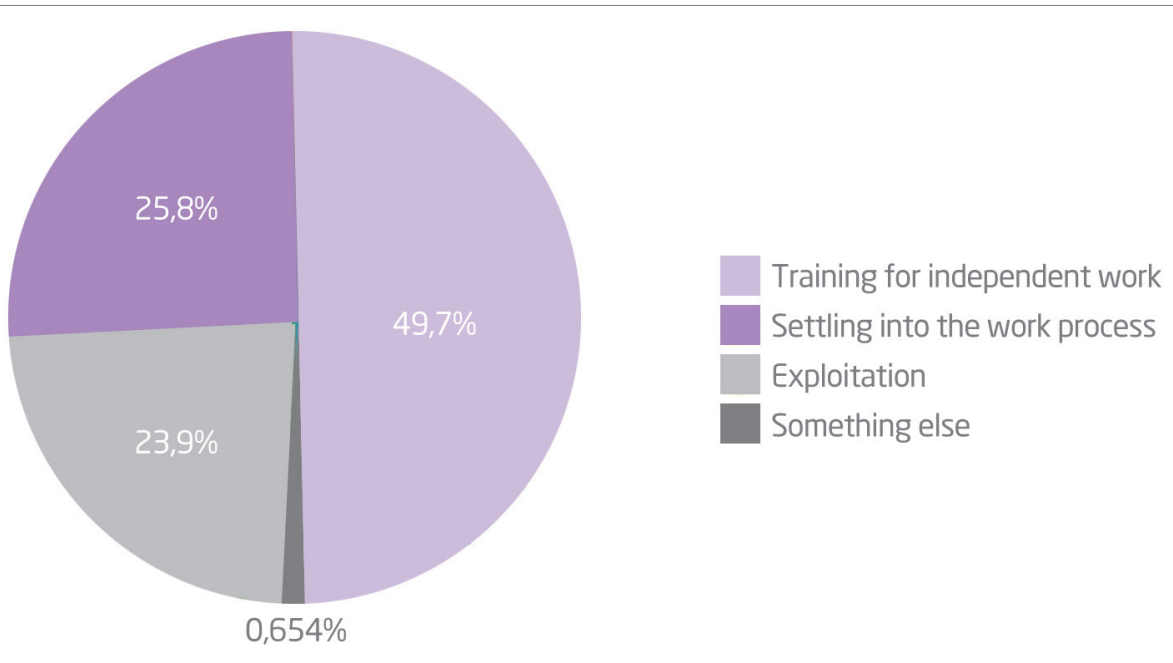

Graph 3. Question 3. "What is your association when you find out that someone is doing an

majority of healthcare workers (59.9\%) considering it to be needed while the percentage of nursing interns with the same attitude is much smaller (22.4\%), and most of respondents (73.5\%) believe that internship is needed but with certain changes introduced.
With regards to the current compensation for work, 230 respondents $(75 \%)$ consider the compensation insufficient; it is considered as sufficient by 75 (24.5\%) respondents, and 1 respondent $(0.3 \%)$ considers is to be too high. 


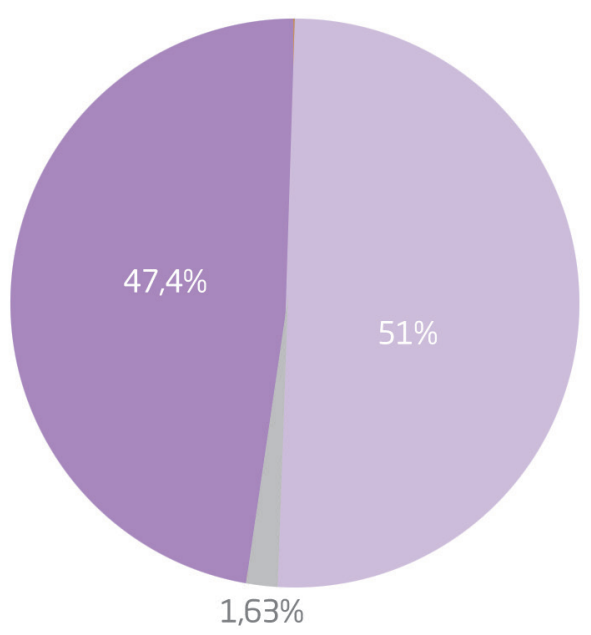

Definitely needed

Needed with certain changes

Not needed

Graph 4. Question 4: "Do you think that internship is necessary in health care?"

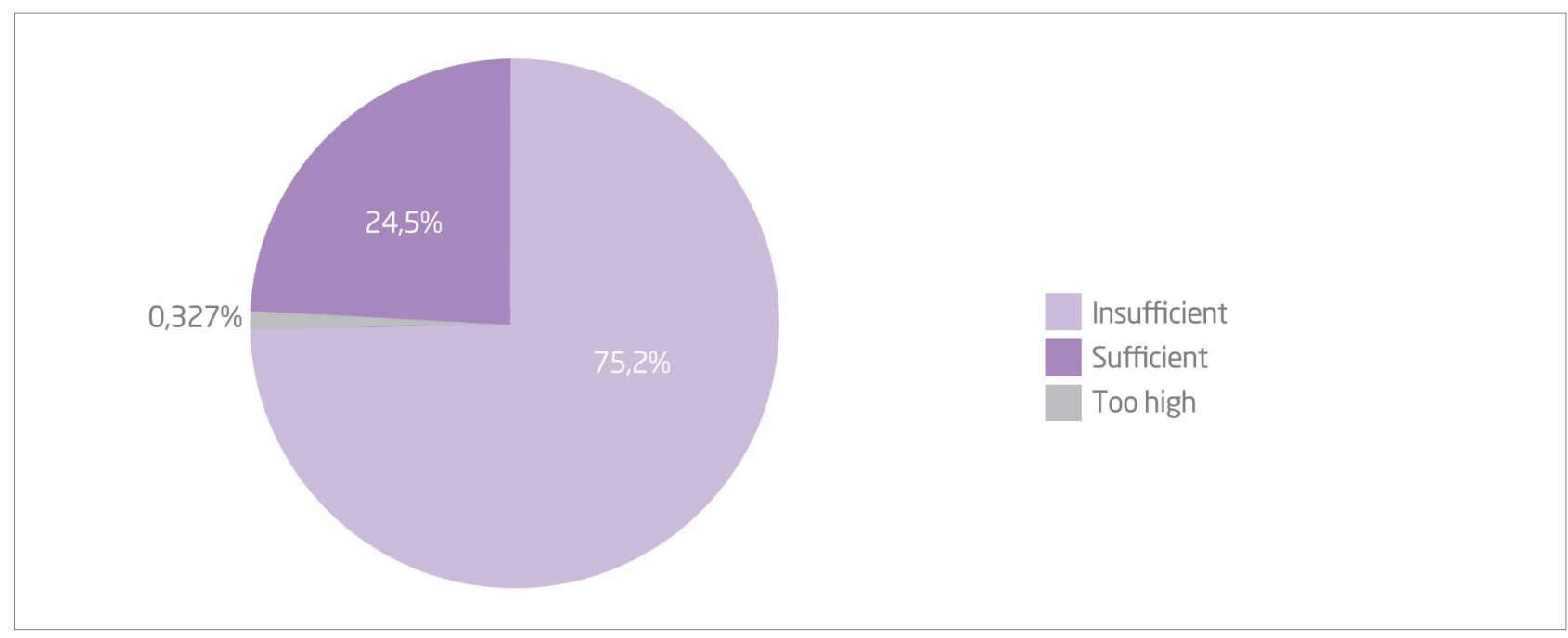

Graph 5. Question 5:

"What is your opinion about the current financial compensation for internship? (2751 kn/month)"

Table 3. Chi-square test of the differences between the groups in the answer to the question "Do you think that internship is necessary in health care?"

Do you think that internship is necessary in health care?

\begin{tabular}{|c|c|c|c|c|c|c|}
\hline & & & $\begin{array}{l}\text { Definitely } \\
\text { yes }\end{array}$ & Definitely not & $\begin{array}{l}\text { Yes, with some } \\
\text { changes }\end{array}$ & Total \\
\hline \multirow{3}{*}{$\begin{array}{l}\text { Your status in the } \\
\text { healthcare system: }\end{array}$} & $\begin{array}{l}\text { Employed in } \\
\text { health care }\end{array}$ & $\begin{array}{l}\text { Frequency } \\
\text { Percentage }\end{array}$ & $\begin{array}{c}139 \\
59.9 \%\end{array}$ & $\begin{array}{c}2 \\
0.9 \%\end{array}$ & $\begin{array}{c}91 \\
39.2 \%\end{array}$ & $\begin{array}{c}232 \\
100 \%\end{array}$ \\
\hline & $\begin{array}{r}\text { Healthcare } \\
\text { intern }\end{array}$ & $\begin{array}{l}\text { Frequency } \\
\text { Percentage }\end{array}$ & $\begin{array}{c}11 \\
22.4 \%\end{array}$ & $\begin{array}{c}2 \\
4.1 \%\end{array}$ & $\begin{array}{c}36 \\
73.5 \%\end{array}$ & $\begin{array}{c}49 \\
100 \%\end{array}$ \\
\hline & Total & $\begin{array}{l}\text { Frequency } \\
\text { Percentage }\end{array}$ & $\begin{array}{c}150 \\
53.4 \%\end{array}$ & $\begin{array}{c}4 \\
1.4 \%\end{array}$ & $\begin{array}{c}127 \\
45.2 \%\end{array}$ & $\begin{array}{c}281 \\
100 \%\end{array}$ \\
\hline
\end{tabular}


Table 4. Chi-square test of the differences between the groups in the answer to the question "What is your opinion about the current financial compensation for internship? (2751 kn/month)"

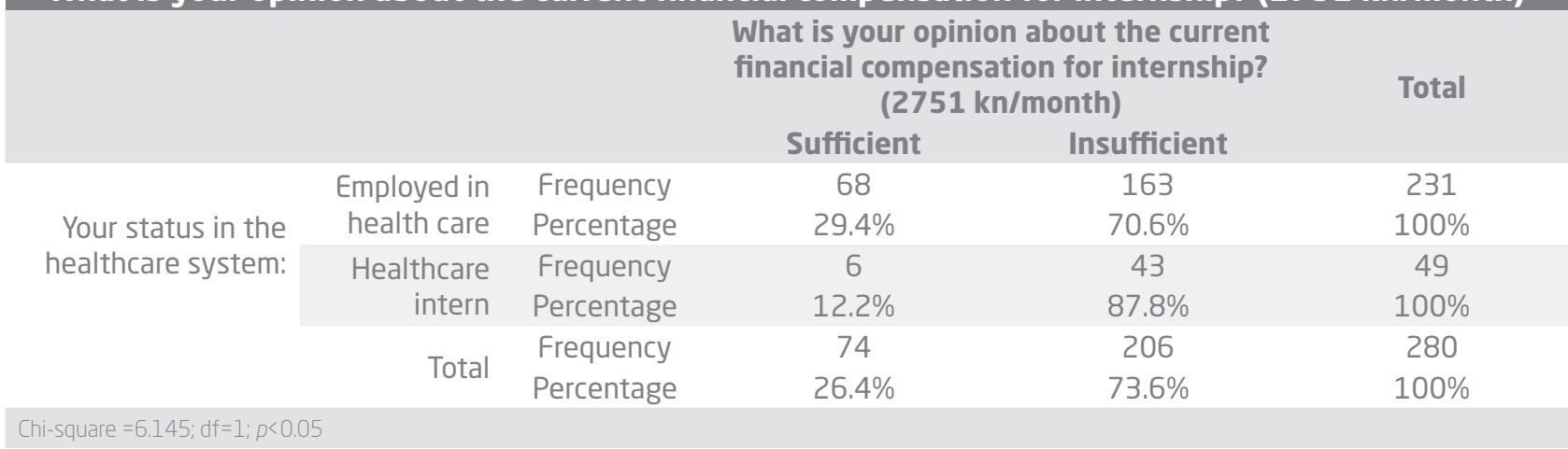

Even though most respondents in both groups believe that the current compensation for internship is insufficient, there is still a statistically significant difference in their ratio, with $87.8 \%$ of interns considering this compensation to be insufficient, while for healthcare workers that ratio is lower (70.6\%, Table 4). In order to increase the statistical strength of the chi-square test, the answer "Too high" given by only 1 respondent $(0.3 \%)$ was exempted from the analysis.

When asked if internship should be included in the years of employment, 289 (94.4\%) of respondents believe it should be fully included. A smaller number of respondents $(14,4.6 \%)$ thinks it is necessary to be included but a year of internship should stand for half a year of employment, while $3(1 \%)$ consider that internship does not need to be included.

Table 5 shows that there is no statistically significant difference between the groups considering whether internship should be included in the years of service; most of the participants in both groups (93.8 and $95.7 \%$ ) believe that it should count as one year of employment. In order to increase the statistical strength of the chi-square test, the answer "No, it does not count as work" was exempted from the analysis since it was chosen by only three participants (1\%).

For responsibility for mistakes, of the total number of respondents, 177 (57.8\%) consider that mentors and interns should share the responsibility. 113 respondents $(36.9 \%)$ think that mentors should take full responsibility, while 16 respondents $(5.2 \%)$ believe that interns are entirely responsible.

Table 6 shows that there is no statistically significant difference in the opinion of whether interns should be held responsible for the mistakes they make, with the majority of both groups considering that the responsibility should be divided between the mentor

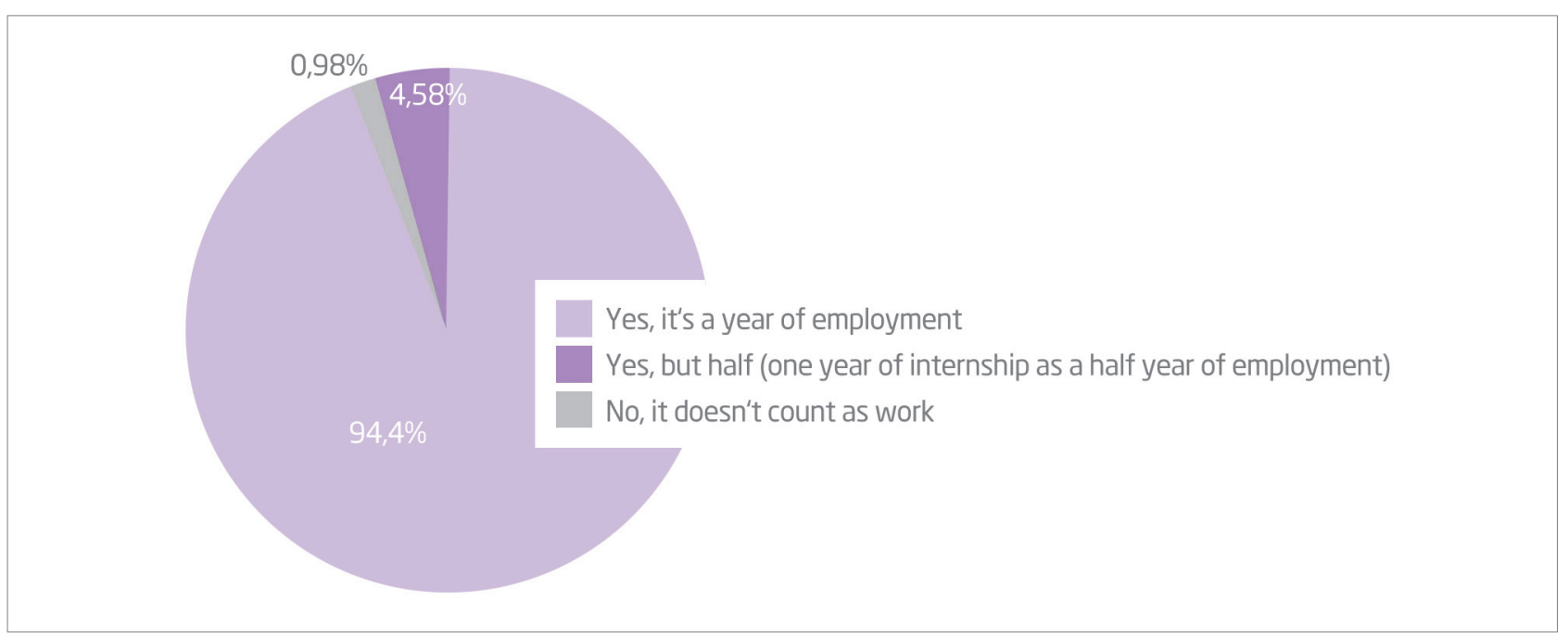




\section{Table 5. Chi-square test of the differences between the groups in the answer to the question} "Do you feel that internship should be included in the years of service?"

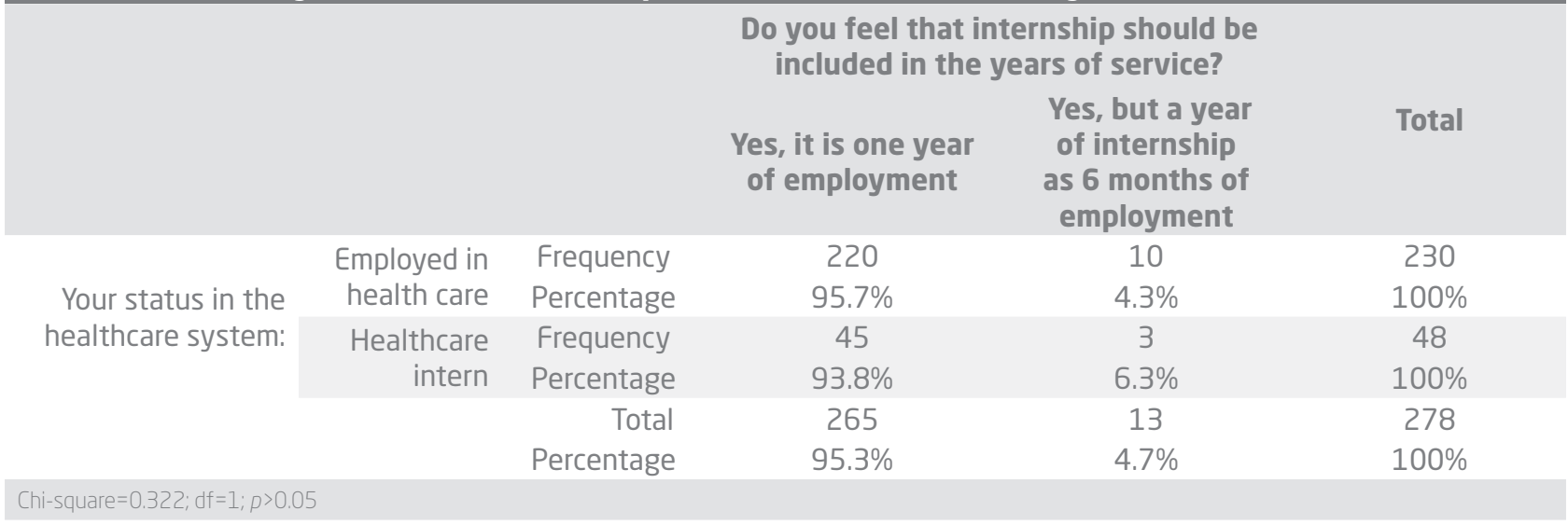

\section{Table 6. Chi-square test of the differences between the groups in the answer to the question} "Should interns be responsible for mistakes they make in their work?"

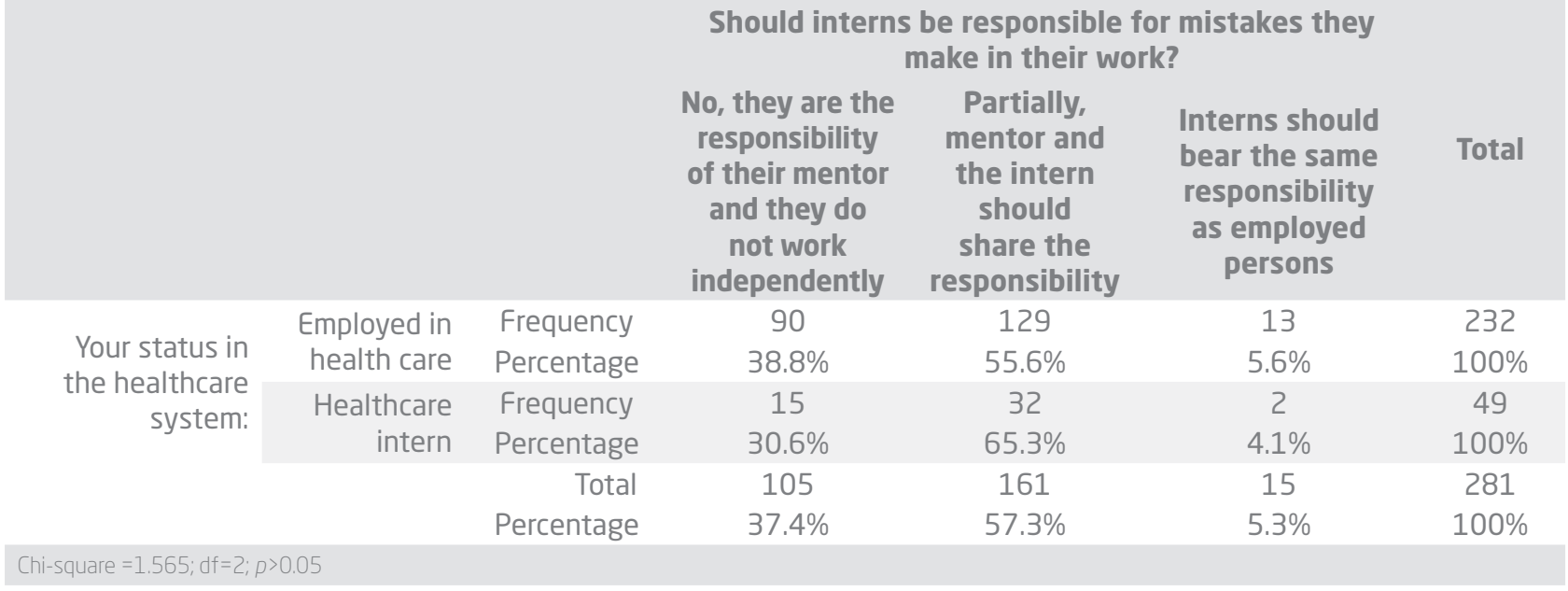

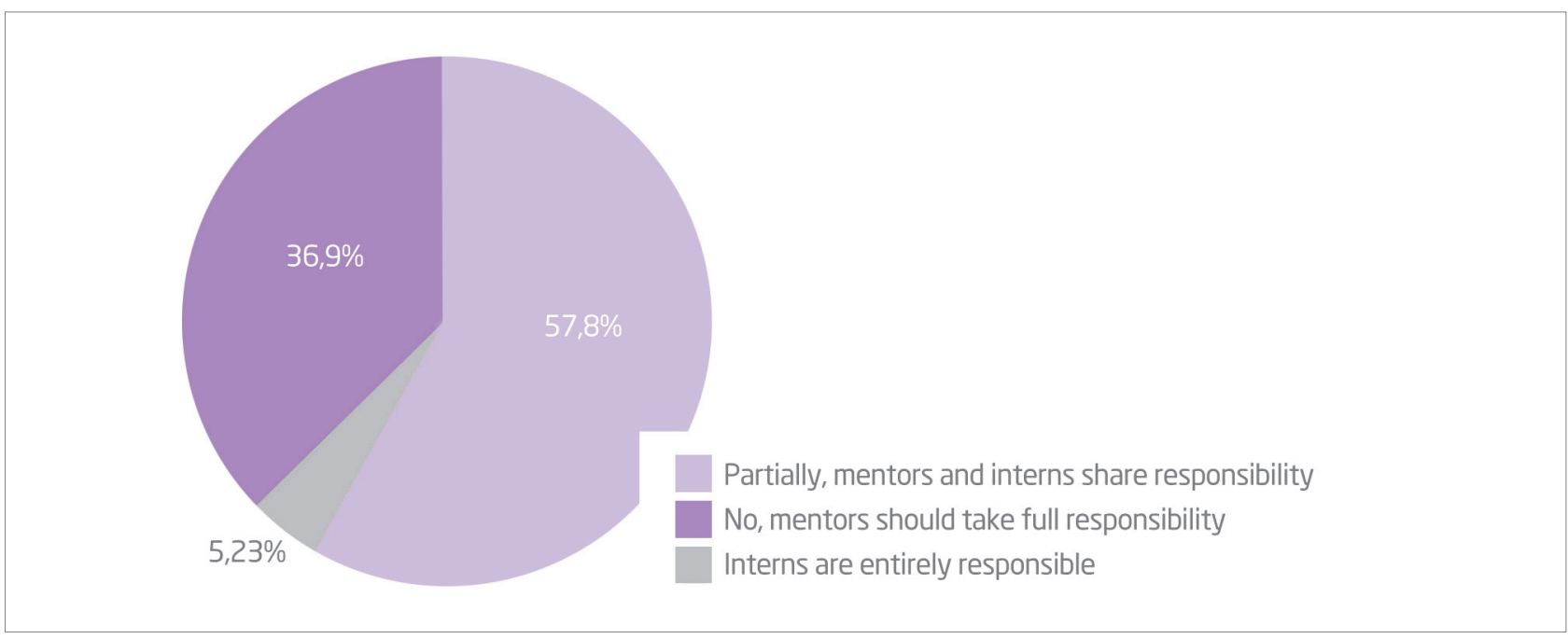




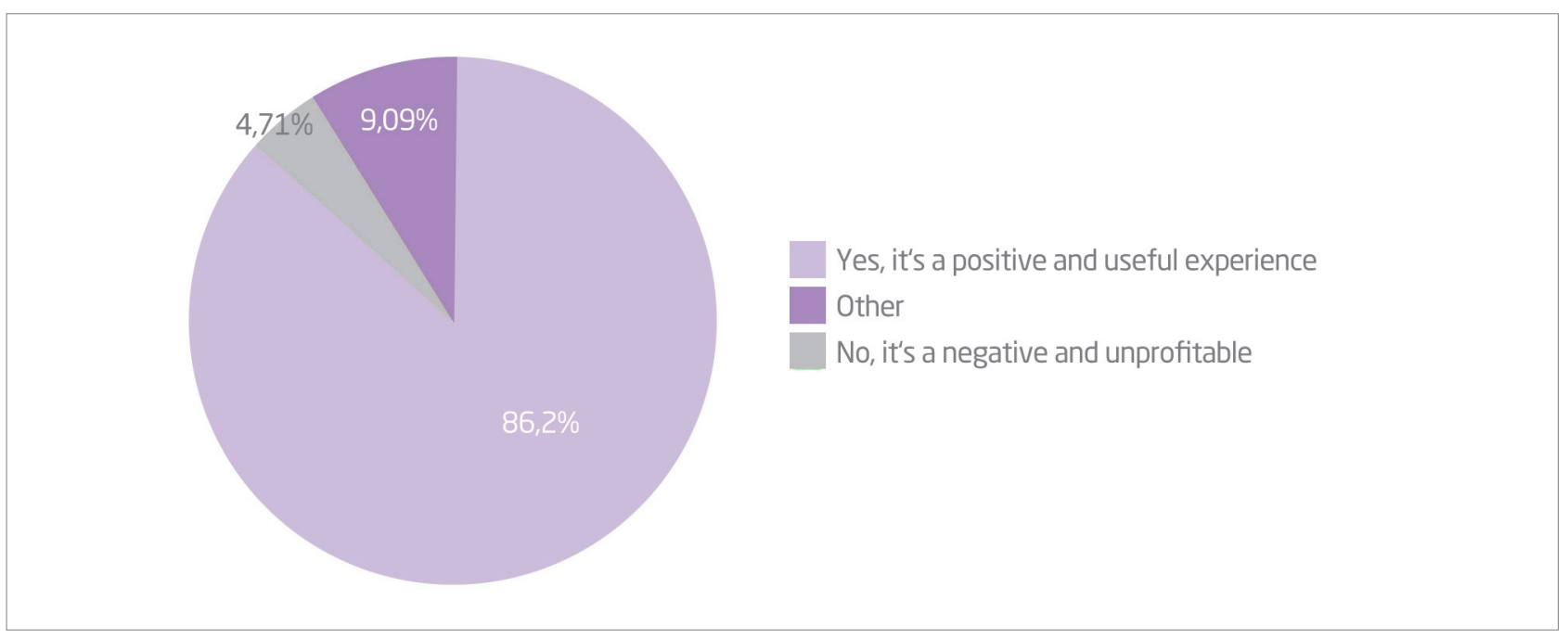

Graph 8. Question 8:

"Would you want a person you care about have the obligation of doing an internship?"

and the intern equally (55.6\% and $65.3 \%)$. Only a small share of the participants believes that interns should bear the same responsibility as persons who are employed (4.1\% to $5.6 \%)$.

Out of the total number of respondents, $265(86.2 \%)$ believe that internship is a positive and useful experience, 14 respondents $(4.7 \%)$ consider it to be negative and unprofitable. 27 respondents (9.1\%) answered "Other".

There is no statistically significant difference in the ratio of responses to a question about whether they would want a person they care about have the obligation of doing an internship (Table 7). In order to increase the statistical strength of the chi-square test, the answer "Other" chosen by 27 participants (8.8\%) was exempt from the analysis, and it did not give any additional information on the attitudes of the participants.

Question 9: "What do you think the person should learn during internship? Write 3 things ranked by order of importance. Example: responsibility, independence, work skills"

Table 7. Chi-square test of the differences between the groups in the answer to the question "Would you want a person you care about have the obligation of doing an internship?"

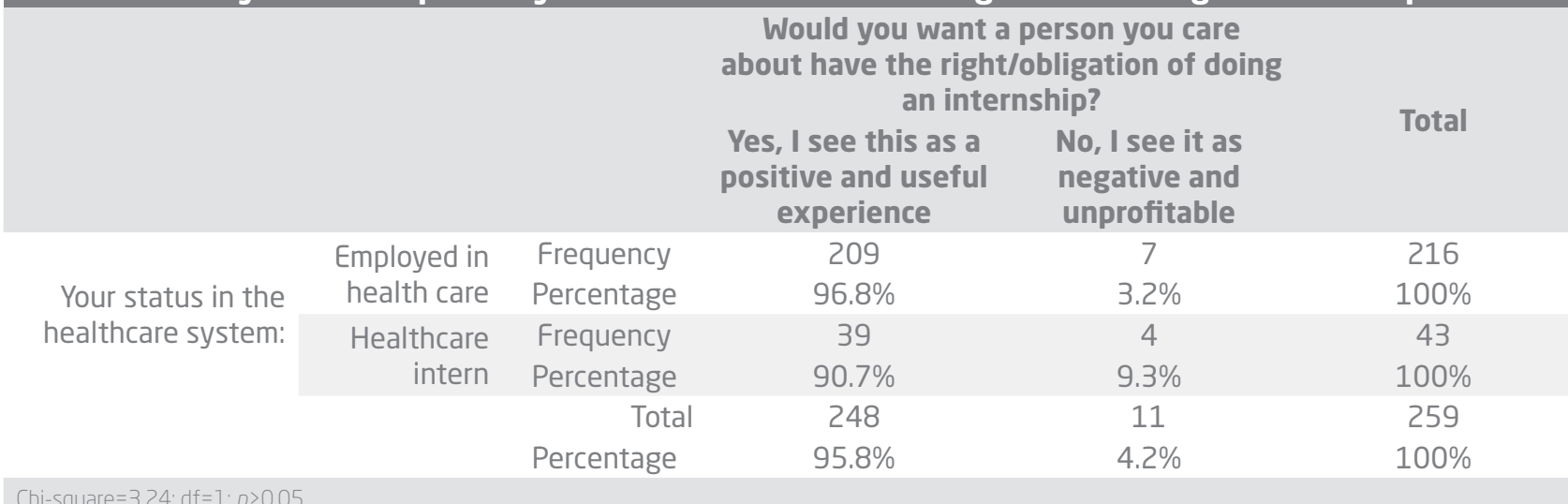


There are 257 responses in total. We singled out the most common and the special ones:

- Work skills, responsibility, independence (11)

- Work skills, independence, responsibility (11)

- Responsibility, work skills, independence (9)

- Responsibility, independence, work skills (4)

- Independence, work skills, responsibility (3)

- Independence, responsibility, work skills (2)

- Independence, work skills, communication

- Work skills, patient relationship, responsibility

- Independence, teamwork, responsibility towards work, organization

- Work skills, managing work tasks, applying theory to practice

- Code and rules of behavior towards employees and patients, teamwork, dealing with limited time and resources, dealing professionally with all members of the health team, patients and family

- Applying intravenous and intramuscular therapy, inserting urinary catheter and venous cannulation

The most important things an intern needs to learn were already provided as answers and those were, e.g., work skills, responsibility, and independence. Of the other answers, there are various statements concerning nursing practice such as: teamwork, patient relationship, specific skills such as drawing blood, inserting urinary catheter and nasogastric intubation, work habits, empathy, code and rules of behaviour, time management and management of other resources etc.

Question 10: $A$ brief comment of the topic, your attitude, explanation, suggestion for changes: (Not required)

There are 94 answers in total, of which 87 are positive towards the internship, while 7 are negative. Some answers are singled out.

1. "I consider discontinuing a one-year internship a major degradation of a nursing profession, something that could ruin the whole concept and reputation of the profession."

2. "90\% of today's youth (from my own experience) think that they have all the knowledge after finishing their education, but it turns out that this is not true and that they really need that one year to settle into their job, to gain work habits and responsibility."
3. "My opinion is that it is absurd that there is no internship because, unfortunately, while in the school, you do not get so much knowledge and skills. During internship you are thrown into work, so you need to manage in different situations and that's the only way to learn how to do the job."

4. "I think that practical training you have during education is simply not enough, especially for people who have enrolled into a higher level of education in a profession that is not healthoriented."

5. "In health care, firstly,our school education is not adequately arranged, you learn one thing at school/university, and at work you do something else. During internship, you lose one year of your life providing nursing care instead of nurses who are employed at those departments and you do not want to be impolite, there are a few honorable exceptions, but all in all, internship does not serve its purpose."

6. "The intern does not know, he or she has no experience (especially if he was a secondary school student), and all the work and great stress falls on the nurse in whose shift the intern works. This is by no means all right and eventually the patients suffer because of it."

7. "Personally, I think that internship is a desirable and definitely important experience because there is no better way to introduce a young person into the work of healthcare workers."

8. "Internship serves the interns to gain responsibility and to understand the weight of their actions as well as their responsibilities. The mentor can speak and teach and show, but without their desire, knowledge and responsibility towards the job, there are no results."

9. "I think internship is a great thing that any person who has chosen a healthcare profession should go through. Personally, this was a wonderful year which I would like to repeat. Before internship not much is known." 


\section{Discussion}

Knowledge, responsibility and skills are often mentioned in this research. In an Indian town Chennai, there was a study of the attitudes of students in their last year of undergraduate study towards nursing internship. A total of 43 students participated in the research and $96 \%$ stated that during internship they have to strengthen 3 aspects: knowledge, skills and attitudes (9). The research carried out in the Republic of Croatia mentions knowledge, skills and responsibility, while in the research in Turkey, knowledge, skills and attitudes are pointed out. The difference is that in the research in Croatia, instead of attitude, responsibility is mentioned. Despite this difference, the results of that research do not contradict the results obtained in this research, which only strengthens the credibility of the attitudes towards internship of a larger number of people. Strengthening the competences needed for independent work with a mentor is of great importance as stressed in many answers to open-ended questions in this research. It is also important to point out that the role of the educator/mentor is significant. While there is officially no mentor for employee training, in the case of internship there is a clearly defined person for an individual intern. A study was conducted in Saudi Arabia with the aim of investigating how much new nurses learn while working with a mentor/ supervisor. They call it "preceptorship" and it is similar to internship. The study included 92 nurse interns who completed a five-year nursing study. The influence of supervised work on strengthening clinical competences required for independent work was investigated. The results have shown that interns have improved their competences primarily in prioritizing care for acute patients, multitasking, and complex nursing skills. Most of the interns considered working with a mentor a very useful experience. It was concluded that interns significantly strengthen the competences needed for independent work while supervised by mentors in charge of education at work (10). The conclusion was that nurses in Saudi Arabia learn a lot of skills important for independent work during supervised work, which could be identified with nursing internship in the Republic of Croatia. Another such study was conducted at Karlovac General Hospital, and it demonstrates the importance of mentors in the training of young nurses. The purpose was to describe the results of the evaluation in order to obtain answers as to how could teachers/mentors themselves improve daily work activities and consequently find new models, methods and strategies for improving the quality of education (11). The importance of mentoring has been re-established, even though it was only the case of clinical practice, and the same was also established for internship. Similar research was also conducted at Clinical Hospital Centre Zagreb. The aim of the research was to examine the mentoring styles in the professional training of nursing bachelors and to establish the connection between the mentoring style and the mentor's qualifications, place of work, years of work experience and study year during which he mentors at a health institution. There was a significant difference with regard to the mentor's professional qualification and place of work. Mentors with undergraduate education act more as counsellors and have a higher level of cooperation with the interns than mentors with graduate degrees. Furthermore, mentors working in hospital departments and primary health care have a higher level of cooperation than mentors in intensive care (12). It was concluded that further research in the field of mentoring and nursing supervision is required.

In the answers to the 10th question of this research, there is often dissatisfaction with the exploitation of interns for doing "less significant" jobs, and a burnout syndrome after a certain time may be noticed. The research in Turkey has shown how internship affects work dedication and burnout syndrome later in work. The study was conducted on 101 students, and it included surveys for students of the final years. The research showed general satisfaction with their job, increased dedication towards work after internship, but also a rise in the burnout syndrome during lengthy exposure of interns to less important jobs (13). The results confirm the importance of internship for later progress and skills development as in the results of this research. These results can be supported by a similar research carried out in Ireland. Midwives' attitudes during internship were investigated. Although this is a different health profession, the results also include the importance of internship in consolidating clinical skills, building trust and competencies relevant for midwifery practice (14). Not everything depends on the importance of mentoring. In order to facilitate the transition from the role of a 
student to the role of a nurse, the cooperation of the educational and health system is necessary (15).

Even though the research of the attitudes of nurses towards the discontinuation of internship has not yet been conducted in the Republic of Croatia, there is a lot of similar research on the attitudes of nursing interns throughout the world. The fact is that most of the research is closely related to work under supervision and mentoring. Respondents are largely in agreement that internship, or its alternative, is definitely needed in nursing.

\section{Conclusion}

The attitudes of nurses towards internship have been determined in this research. From the results, it is very clear that most respondents consider internship necessary in healthcare. Respondents agree that internship, or its alternative, is necessary for nursing and its discontinuation will not contribute to the progress of the nursing profession. There were statistically significant differences between employee and interns' attitudes towards this issue. Interns rate their knowledge of internship poorer than employed nurses, and have different associations and attitudes.

The results clearly show the disadvantages of internship; misapplication, poor financial compensation, exploitation, insufficient training of the interns, and the like. Although internship has been discontinued, it is necessary to state that $98.6 \%$ of the respondents consider that internship is necessary in health care.

The research states the unquestionable importance of quality mentoring, therefore, employers should be responsible for securing nurse educators who would educate young nurses about the basics, but also the specifics of the job. In such a way, sufficient attention to new workers and also new jobs for nurse educators would be provided.

\section{References}

1. Zdravstveno veleučilište Zagreb. Studijski program preddiplomskog stručnog studija sestrinstva; 2016. Available from: https://www.zvu.hr/wp-content/uploads/ SE.pdf Accessed: 30.05.2018. Croatian.

2. Čukljek S. Povezanost prethodne izobrazbe i stavova studenata studija sestrinstva o sestrinstvu kao profesiji [disertacija]. Zagreb: Medicinski fakultet Sveučilišta u Zagrebu; 2016. Croatian.

3. Domitrović DL. Obrazovanje medicinskih sestara u Republici Hrvatskoj u usporedbi sa standardima Europske unije [diplomski rad]. Zagreb: Medicinski fakultet Sveučilišta u Zagrebu; 2016. Croatian.

4. Mrnjec V. Povijesni pregled obrazovanja medicinskih sestara u Republici Hrvatskoj. Sestrinski glasnik. 2014;19:246-9. Croatian.

5. Naraks I. Practice firm model - getting competences with method "Learning By Doing". Entrepreneurial learning. 2002;(2)2:207-15.

6. Narodne novine. Pravilnik o pripravničkom stažu zdravstvenih radnika. Zagreb: Narodne novine d.d. 2011;33:1-9. Croatian.

7. Stručno osposobljavanje za rad bez zasnivanja radnog odnosa. Ministarstvo rada i mirovinskoga sustava; 2017. Available from: http://mjere.hr/strucno-osposobljavanje-rad-bez-zasnivanja-radnog-odnosa Accessed: 30.05.2018. Croatian.

8. Mjere za stjecanje prvog radnog iskustva. Ministarstvo rada i mirovinskoga sustava; 2017. Available from: http://mjere.hr/potpore-zaposljavanje-stjecanje-prvogradnog-iskustva-pripravnistvo/ Accessed: 30.05.2018. Croatian.

9. Suresh H. Perception of nursing students towards internship. Nurs J India. 2012;103(2):59-61.

10. Aboshaiqah A, Qasim A. Nursing interns' perception of clinical competence upon completion of preceptorship experience in Saudi Arabia. Nurse Educ Today. 2018;68:53-60.

11. Cazin K. Evaluacija rada mentora. Sestrinski glasnik. 2013;18(1):18-23. Croatian.

12. Režić S. Metode mentoriranja prvostupnica sestrinstva. Sestrinski glasnik. 2016;21(3):200-3. Croatian.

13. Ayaz-Alkaya S, Yaman-Sözbir Ş, Bayrak-Kahraman B. The effect of nursing internship program on burnout and professional commitment. Nurse Educ Today. 2018;68:19-22.

14. Bradshaw C, Murphy Tighe S, Doody O. Midwifery students' experiences of their clinical internship. Nurse Educ Today. 2018;68:213-7.

15. Čukljek S, Ledinski Fičko S, Hošnjak AM, Smrekar M. Nursing Students Opinion on Knowledge Need for Nursing Practice and Self Assessment of Adopted Competencies at the End of an Undergraduate Study Programme. Croat Nurs J. 2017;1(1):61-72. 


\section{STAVOVI MEDICINSKIH SESTARA/TEHNIČARA O PRIPRAVNIČKOM STAŽU U REPUBLICI HRVATSKO]}

\section{Sažetak}

Pripravnički staž u zdravstvu je reguliran Pravilnikom o pripravničkom stažu zdravstvenih radnika. Jedna je od mjera Hrvatskog zavoda za poticanje zapošljavanja pripravnika u zdravstvu „stručno osposobljavanje za rad bez zasnivanja radnog odnosa".

Cilj je ovog istraživanja istražiti stavove o pripravničkom stažu te utvrditi postoji li statistički značajna razlika u stavovima trenutačno zaposlenih medicinskih sestara/tehničara te onih koji trenutačno obavljaju pripravnički staž.

Istraživanje se provodilo putem interneta, anonimnim anketama s 10 pitanja, od toga osam pitanja s ponuđenim odgovorima te dva pitanja otvorenog tipa. Ukupno se odazvalo 306 ispitanika, od toga su 232 medicinske sestre / medicinska tehničara te 49 medicinskih sestara/tehničara pripravnika. Na pitanje smatraju li pripravnički staž potrebnim u zdravstvu $98,4 \%$ ispitanika odgovorilo je pozitivno, pri čemu većina pripravnika (75,3 \%) smatra da su potrebne izmjene pripravničkog staža. Rezultati hi-kvadrat testa govore u prilog tome da u odgovorima na pet pitanja postoje statistički značajne razlike u stavovima zaposlenih i pripravnika. Pripravnici su znanje o pripravničkom stažu ocijenili lošijim u odnosu na zaposlenike u zdravstvu i u drugim sustavima. Pripravnike pripravnički staž asocira na iskorištavanje, dok zaposlene osobe navode da ih asocira na osposobljavanje za samostalan rad. Većina zaposlenih u zdravstvu željela bi da njima bliska osoba ima pravo/obvezu odraditi pripravnički staž.
Analizom rezultata stavova prema pripravničkom stažu utvrđena je statistički značajna razlika među zaposlenicima i pripravnicima. Smatra se da velika odgovornost u osposobljavanju mladih prelazi na poslodavce koji bi trebali osigurati adekvatne edukacije i stalna praćenja novih radnika.

Ključne riječi: staž, sestrinstvo, prednosti, nedostaci, stavovi, pripravnici 